\title{
A NATIONAL DNA DATABASE FOR SRI LANKA
}

\author{
Ravindra Fernando \\ Senior Professor of Forensic Medicine and Toxicology \\ Faculty of Medicine, University of Colombo, Sri Lanka.
}

Many countries facing rising tendencies of crime continuously consider methods to combat them. A speedy and efficient criminal justice system with improved methods of policing, using modern crime investigation techniques, efficient prosecuting service and an independent proactive judiciary are the hallmarks of a country geared to reducing crime.

Quick identification of a criminal plays an essential role in an effective criminal justice system. To identify people various scientific methods have been used since 1880s. One was anthropometry - the measurement of the human body. Alphonse Bertillon, an official at the Paris police prefecture, recorded eleven anthropometric measurements. The results were recorded on a printed card and were filed according to which category they fell into for the measurements. When a suspect is found all eleven measurements were recorded and the existing criminal records for a card containing very similar measurements were searched and matched. Anthropometric identification was rapidly adopted by prisons and police departments worldwide by $1890 \mathrm{~s}^{1}$.

Scientists realized that fingerprint patterns were probably inherited by the late nineteenth century. Sir Francis Galton, one of the pioneers of the modern system of fingerprint identification, classified all fingerprint patterns into three groups: arches, loops, and whorls. In 1892 he published a study of the frequency with which these three pattern types appeared among various races (2) (3). Fingerprints, computerized or not, are still used in identification.
Criminal identification changed dramatically in the last few decades as a result of a single experiment.

At 9:05 am on 10 September 1984, Alec Jeffreys of the University of Leicester was looking at the X-ray film image of a DNA experiment. It unexpectedly showed similarities as well as differences between the DNA of different members of his laboratory technician's family. Jeffreys realized within about half an hour the possible scope of DNA fingerprinting, which uses variations in the genetic code to identify individuals. After he published the findings and interpretations his technique became a widely used tool to solve crime all over the world ${ }^{(4)(5)}$.

A DNA (Deoxyribose Nucleic Acid) profile is a "genetic fingerprint", unique to each person. They can be identified from analysis of cells, including from tiny samples of blood, semen, saliva, skin or even sweat.

DNA fingerprinting was first put to use by Jeffreys in an immigration case to confirm the identity of a British boy whose family was originally from Ghana. The DNA results proved that the boy was closely related to the other members of the family, to the great relief of the mother ${ }^{(6)}$.

DNA fingerprinting and mass DNA screening was first used as a police forensic test to identify the rapist and killer of two 15 year old, Lynda Mann and Dawn Ashworth, who were murdered in Leicestershire, in 1983 and 1986 respectively. Colin Pitchfork was identified 
and convicted of murder after samples taken from him matched semen samples taken from the two dead girls ${ }^{(6)}$. He was arrested in 1987, and sentenced to life imprisonment after admitting both murders. If not for the DNA, an innocent man who was the main suspect would have inevitably been convicted.

As reports from world over emphasised the value of DNA profiling in criminal justice, in mid nineties I gave a proposal to establish a DNA laboratory for crime work in Sri Lanka to a Secretary of an important and relevant Ministry. Regrettably, no action was taken by the authorities. While efforts were being made some academics to establish a laboratory in the Faculty of Medicine, University of Colombo, a DNA laboratory was opened in the private sector. Subsequently, the Faculty of Medicine, University of Kelaniya has developed facilities for DNA profiling.

I used DNA profiling to express an opinion in a case of disputed paternity in early nineties when a father wanted to know whether the 2 year-old daughter was his, or his wifeôs boy friend. Mother, who admitted to the extramarital affair, was not sure! With the consent of parents, blood from all three was sent to a laboratory in Australia for DNA profiling. Fortunately, the daughter, to whom the father was very attached to, was proved to be his.

In a criminal case, DNA profiling was used for the first time in Sri Lanka when six family members (the father, mother, three daughters and the son) were murdered in Hokandara, a small town near the capital, in late nineties. One of the alleged murderers was also found dead at the scene of the crime. Three other suspects were arrested the same day. Bloodstains from the clothes of three suspects were typed for DNA revealing an identical pattern, indicating that the blood was from one individual. An identical DNA profile was also observed for the murdered son ${ }^{\text {(7) (8). }}$

Although the link between the suspects and the victims were made, and DNA evidence was presented at the trial, as there was adequate circumstantial evidence, it is not clear whether DNA evidence assisted the court to convict the suspects.

In 2008, there were 60870 grave crimes reported to the police in Sri Lanka. Of this, there were nearly 1500 homicides, 400 attempted homicides, over 450 unnatural offences/grave sexual abuse cases and over 1500 rapes in $2008^{(9) .}$

Considering the statement made by a former Inspector General of Police a few years ago, only $4 \%$ who committed these crimes are eventually convicted in Sri Lanka. The other murderers, rapists and robbers escape punishment and have many opportunities to commit these crimes again.

National DNA databases (NDNADs) have been created in several countries. The United Kingdom was the first European country to establish a NDNAD in 1995. The Netherlands and Austria (in 1997), Germany (in 1998), Finland and Norway (in 1999) have started databases and many others are preparing databases ${ }^{(10) .}$

In the United States of America (USA), DNA database laws authorizing the creation of DNA databases rapidly spread through all fifty states during the 1990s ${ }^{(11)}$.

When the idea of NDNAD was put forward in 2001, Professor Sir Alec Jeffreys, who has considerable concerns over civil liberty issues, stated that he was in favour of this as the potential of this database to prosecute serious crime, to save the lives and the misery of future victims is very substantial (12) (13).

The police in England and Wales now have the worldô biggest per capita DNA database and takes mouth swabs from everyone they arrest. They now hold samples from some 5.3million people whether they have been convicted of an offence or not - nearly nine per cent of the population. 
The value of having a NDNAD include,

(a) Identifying criminals by matching crime scene and other evidence

(b) Exclude the innocent, saving them and their families from physical and mental distress.

(c) Shortened police investigation and trial hearings saving time and resources.

(d) Saving cost for investigating additional crimes committed by perpetrators.

(e) The deterrent effect on criminals of a NDNAD.

(f) Identification of disaster victims even if the victim does not have a DNA sample on file in a database.

I wish to present 4 cases to highlight the value of a NDNAD.

\section{Case 1}

On March 3, 1986, Debbie Smith was abducted from her home in Williamsburg, Virginia, USA. She was robbed, and raped. The subsequent police investigation reached a dead end. Nine years later, on July 26, 1995, the newly-entered DNA profile of a prisoner, Norman Jimmerson, matched the semen collected from the rape kit. Jimmerson was subsequently convicted and sentenced to two life sentences plus 25 years with no chance of parole. Debbie Smith testified after the conviction, ñ..Finally, I could quit looking over my shoulder. No longer did I have to drive around in circles hoping a neighbour would drive by so I could get the courage to get out of my car to go into my own front door if no one else was home. Unfamiliar noises no longer left me panic-stricken... Suicide was no longer a consideration. And finally, my husband is grateful that I donô wake him up anymore in the middle of the night with the ear-piercing screamsò(14).

\section{Case 2}

16-year-old Colette Aram was abducted, raped and strangled and her body was dumped in a remote field in 1983, when she was walking to her boyfriend's house in the Nottinghamshire village of Keyworth, England. A DNA profile of the suspect was created in October 2008 from samples taken from the scene and a local pub the suspect visited straight after the murder. Police regularly ran the profile through the national database for a match. But detectives had to wait another six months for the breakthrough that they needed.

In June 2008, a 20 year-old man was arrested for drink-driving and gave police a sample. When experts carried out a familial DNA search it showed a near identical match to Coletteôs killer. Police then investigated his family and his father Hutchinson was arrested. He blamed the murder on his dead brother. After he was told that detectives had his brotherô DNA and it was not a match for the crime scene, Hutchison admitted guilt. After a trial at Nottingham Crown Court he was convicted and jailed.

Coletteôs case achieved huge publicity after being the first ever to be featured on the BBC programme ñCrimewatchò in June 1984. This monthly live programme, which I had the privilege to see live broadcasting in a BBC studio in nineties, informs the public about unsolved crime. It requests information and witnesses to contact the programme direct or the police (15) (16).

\section{Case 3}

Nine-year-old Imraan Vohra last seen leaving his school in Preston, Lancashire, in July 1985 . His body was found raped and strangled in undergrowth of a nearby park two days later. During a lengthy police investigation, more than 6,000 people were contacted, 2,500 statements were obtained and hundreds of items of evidence stored on a computer database. Over the years swabs and stains of Imraanô trousers were regularly examined using new DNA techniques as they became available. Eventually a complete DNA profile of the 
suspect was obtained. A familial search pinpointed a family member of the suspect who lived more than 150 miles away from the crime scene. The suspect was identified 24 years after the murder as Robert Morley, a father of seven. Morley had died of lung cancer in 1997. His DNA was matched with a biopsy sample retained in a hospital (17).

\section{Case 4}

On May 1, 1990, Roy Criner was convicted of the 1986 rape and murder of Deanna Ogg and sentenced to ninety nine years in prison in the USA. Seven years later, a DNA test conducted on the semen left on Oggấ body did not match that of Criner. However, a state district court decision to grant Criner a new trial was overturned in a five-to-four decision by the Texas Court of Criminal Appeals. Their theory was that Ogg might have had consensual intercourse prior to being raped and that Criner might have worn a condom or not ejaculated! Three years later, a cigarette butt from the crime scene was tested. It contained DNA from Ogg and the individual who was the

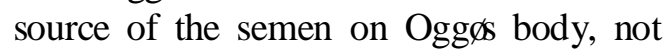
Crinerô. In July 2000, the Texas Board of Pardons and Paroles, at the request of the prosecutor, recommended that Criner be set free (18).

The last case highlights the potential of DNA to identify, even after a conviction, an innocent person by demonstrating that crime scene evidence from the perpetrator of the crime does not match the individual convicted of the crime. There were over 140 convict exonerations in the USA that have resulted from postconviction DNA analysis since 1989. Unfortunately, postconviction exonerations have received far more media publicity, but far less policy action. (19)

It is now time to consider developing a NDNAD in Sri Lanka to use DNA profiles in crime investigation. The Government of Sri Lanka (GOSL) must accept the usefulness of a NDNAD and speedily enact necessary legislation. NDNAD laws should consider provision of adequate resources devoted to the databases, criteria for inclusion/exclusion of individuals in the database, criteria for search, and to establish the NDNAD.

To establish the NDNAD, the GOSL should either establish a separate independent authority with wide powers and resources, or consider an existing institution, such as the Department of Government Analyst or a University. Unfortunately in the present climate, the police should not be considered capable to handle and receive public confidence to establish the NDNAD in Sri Lanka.

It is necessary to obtain equipment and train scientists abroad where NDNADs are well established. A foreign grant may be necessary for this purpose

Although nobody contests today the rewards of a NDNAD in the fight against crime, human rights and fundamental liberties of each individual has to be legally safeguarded, because these databases could be used not only for criminal identification but also to determine an individualôs racial and ethnic heritage, to assess predispositions to certain diseases or behaviours. Therefore, when establishing and maintaining a NDNAD, interests of the society and individual should be clearer balanced. This is because of the possibility of such a database may expand to include millions of individuals who have never been not convicted of any crime.

DNA evidence, like other types of forensic evidence, is subject to laboratory error, proprosecution/pro-defence bias, and overstatement of the scientific certainty of conclusions. Therefore, it is absolutely essential that precautions should be taken to ensure that DNA evidence receives ongoing scrutiny from the courts, the bar, and the scientific community. As Cole has stated, ñt should not be a black box whose conclusions are treated as unassailable, error-free gospel.ò(13) 


\section{References}

1. Horn DG, ñSocial Bodies: Science, Reproduction, and Italian Modernityò 1994. Princeton University Press, New Jersey.

2. Galton F ñFinger Printsò. 1892. Macmillan and Co. London.

3. Cole SA ñSuspect Identities: A History of Fingerprinting and Criminal Identificationò. Harvard University

Press, 2001, 60-96

4. Jeffreys AJ, Wilson V, Thein SL. ñHypervariable minisatellite regions in human DNAò Nature, 1985;314 (6006): 67-73.

5. Jeffreys AJ, Wilson V, Thein SL ñIndividual- specific fingerprints of human DNA,ò Nature, $\quad 1985 ; 316$ (6023):76-9.

6. http://dnaencyclopedia.com/dnatesting/forensic-dna-typing

7. Goonesekere NCW, Gunasekera MB, Fernandopulle N. ñUse of DNA typing for criminal case work in Sri Lankaò Proc. Tenth International Symposium on Human Identification ï 1999 Orlando, USA. August 17-21.

8. Abeyasinghe N, Fernando R, Niranjan S. ñHomicide of six family members using multiple methods in Sri Lanka.ò J Forensic Leg Med. 2009 Nov; 16(8):486-8.

9. http:// www. police.k/ divisions / crime/grave_crime_abstra ct_2008.html

10. Corte-Real F. Forensic DNA databases. Forensic Sci Int. 2004 Dec 2;146 Suppl:S143-4.
11. Axelrad S. Survey of State DNA

Database Statutes.

http://www.aslme.org/dna_04/grid/ guide.pdf

12. http://news.bbc.co.uk/2/low/uk_ne ws/1177160.stm

13. Cole SA. Fingerprint Identification and the Criminal Justice System: Historical Lessons for the DNA Debateò In: DNA and the Criminal Justice System: The Technology of Justice. Ed:Lazer D. (MIT Press, 2004).

14. Smith D, ñTestimony before the Subcommittee on Government Efficiency, Financial Management and Intergovernmental Relationsò. How Effectively Are State and Federal Agencies Working Together to Implement the Use of New DNA Technologies? 107th Cong., $\quad 1^{\text {st }}$ Session, June 12, 2001.

15. Britten N. ñColette Aram's killer jailed for life 26 years after her murderò The Times. 25 Jan 2010.

16. http://www.express.co.uk/posts/vie w/147905/How-DNA-helpedcatch-Paul- Hutchinson

17. Anonymous. ñJustice for Imraanò Clued-up. 2009;109:8

18. Bob Burtman, ñFree at Last,ò Houston Press, August 3, 2000.

19. Lazer D, ñThe Diffusion of DNA Databasesò(Working paper, National Center for Digital Government, John F. Kennedy School of Government, Cambridge, Mass., 2004). 